\section{Inheritance of Milking Capacity}

Now that Mr. Edwards 1 has made the first point of his original letter clear, his criticism is one which has already been suggested, and discussed, by myself. If this criticism were invariably valid, it should also hold good as regards butter-fat yield. In the case of Mr. Madsen's work the argument may be valid, but as I believe his butter-fat figures were calculated on the averages of percentages, this may explain a similarity in the milk and butter-fat figures. A truer indication may be obtained from the work of Robison and myself, to which Mr. Edwards has already made reference, where, despite what Mr. Edwards calls the phenotypic selection of the sires, the butter-fat correlation of granddaughters to their paternal grandsire is the same as to the maternal grandsire.

With regards to points (2) and (3), Mr. Edwards has shifted the grounds of his argument considerably. In one respect he remains consistent, in that he persists in confusing correlations based on genotype with those based on phenotype. Since he still misunderstands the original statcmonts of Mr. Madsen, I feel that little good can result from a further debate upon these points.

As to point (4), I maintain that I was justified in challenging Mr. Edwards as to the accuracy of his calculation that the results obtained by Mr. Madsen might once in ten times be due to chance. I repeat that one in twenty expresses more accurately the possibility of Mr. Madsen's results being obtained by chance. Tables of the normal curve, which, as Dr. Wishart ${ }^{2}$ admits, are for such large samples sufficiently accurate, show that a deviation of $-1 \cdot 64 \sigma$ leaves only one-twentieth of the area to the left of that point. The fact that there is also a second twentieth to the right of the point $+1 \cdot 64 \sigma$ is irrolevant, since positive deviations, however great, could not be cited in support of sex-linkage. The distinction is a simple onc, though frequently overlooked. The point has been fully explained by Dr. R. A. Fisher. ${ }^{3}$

It is now four years since the facts first suggested to me the possibility that the hereditary transmission of milking capacity might be in part conditioned by sex-linked genes. Since that time, I and others have been pursuing this subject along various lines, and we have not yet been able to find a valid reason for jettisoning this hypothesis, which appears to be not only warranted by the results obtained by ourselves and others, but also explains many of the practical difficulties of breeders. Neither I nor my colleagues, however, are wedded to this hypothesis, but we still await criticism which might compel us to modify our views.

A. D. Buchanan Smith.

Institute of Animal Genetics, University of Edinburgh.

1 NATURE, 129, 867, June 11, 1932.

2 Nature, 129, 868, June 11, 1932

"Fisher, R. A., "Statistical Methods for Research Workers", 3rd edition, p. 45 .

\section{Polypharyngeal Planarians}

AMong a dozen specimens of the planarian, Polycelis cornuta Johnson, collected in August 1931 from a small pond at Liss in Hampshire, I obscrved one specimen with a woll-developed donble pharynx. I revisited this pond in March of this yoar and was able to collect several hundred spccimens of the same planarian. In this pond Polycelis cornuta constituted more than 90 per cent of the planarian population, Polycelis nigra and Dendrocclum lacteum being present in small numbers. On examining these specimens of Polycelis cornuta, one was again found with a double pharynx.
Polypharyngeal planarians have frequently been recorded from various districts on the Continent, but, so far as I am aware, this is the first time that this type of abnormality has been recorded from the British Isles. Previous records of polypharyngeal planarians have usually been from mountainous districts, but Thienemann ${ }^{1}$ has recorded finding one spccimen of a tripharyngeal Polycelis cornuta from among a hundred specimens collected from springs in Holstein. The dipharyngeal forms are evidently not common, but, from the fact that they have been found fairly easily in two collections made at different times, it may be assumed that this abnormality is established in the race living in this particular pond. Polycelis cornuta is a fairly common species in Britain and the existence of the double pharynx is quite obvious on examination, even with a simple lens, so that it is unlikely that these abnormal forms would have escaped notice.

The pond in which the dipharyngeal forms occurred is a small one, about five yards in diameter and less than one foot deep. It is on the slope of a hill and is sixpplied by a spring draining out of the soil. Tho temperature of the water of the pond in March 1932 was $6^{\circ} \mathrm{C}$., and this temperature corresponded with that of the local streams. The temperature of deep springs from the chalk in the same district at the same time was $9.5^{\circ} \mathrm{C}$. It can be assumed, therefore, that the water supply of this pond is not from a deep spring, which would maintain an even temperature of the water throughout the year. The temperature of the water in the pond at the time of my visit in March appears to show that it varies with that of the air, in the same way as other ponds and streams supplied by surface drainage.

Zoological Laboratory, Cambridge, June 1 .

1 Zool. Anz., 53, 118; 1921.

\section{Trochus niloticus, Linn. in Andaman Waters}

Dr. Yonce in "A Year on the Great Barrier Reef" (Putnam : 1930) states that certain animals like the horse-hoof clam spawn "at the peak of summer"; others like Trochus niloticus "during the entire winter".

My observations on the bionomics of $T$. niloticus on the east coast of the Andaman Sea reveal (1) that this species grows during tho monsoon and 'winter' months, that is, July to March, and (2) that it starts spawning about the middle of the summer months, that is, April.

The temperature of the Andaman Sea has two definite rises and two falls in a year. ${ }^{1}$ The first riso starts in February, to reach a climax in April-May, before the outbreak of the south-west monsoon; there is a fall during the monsoon. The second rise starts in July-August, to reach its highest point in October, before the north-east monsoon; and finally, the second fall begins in November. The first rise of temperature, that is, the April one, reaches a higher degree than the second, the October one. As remarked above, $T$. niloticus starts spawning in April, and it appears, therefore, that in the Andaman waters this molluse has a minimum temperature above which alone it would spawn. This observation cmphasises the idea that the marine invertobrates in tropical waters do not breed haphazardly but with a similar regularity to that observed in temperate waters. C. Amirthalingam.

Zoological Survey of India, Calcutta, May 16.

1 R. B. S. Sewell, Mem. Asiatic Soc. Rengal, vol. 9.

No. 3272 , VoL. 130$]$ 